\title{
Differential expression of CART in ewes with differing ovulation rates
}

\author{
Jennifer L Juengel ${ }^{1}$, Michelle C French ${ }^{1}$, Laurel D Quirke ${ }^{1}$, Alexia Kauff ${ }^{1}$, George W Smith ${ }^{2}$ and \\ Peter D Johnstone ${ }^{1}$ \\ ${ }^{1}$ Reproduction, Animal Science, AgResearch Limited, Invermay Agricultural Centre, Puddle Alley, Mosgiel, \\ New Zealand and 'Laboratory of Mammalian Reproductive Biology and Genomics, Department of Animal Science, \\ Michigan State University, East Lansing, Michigan, USA \\ Correspondence should be addressed to J Juengel; Email: jenny.juengel@agresearch.co.nz
}

\begin{abstract}
We hypothesised that cocaine- and amphetamine-regulated transcript (CARTPT) would be differentially expressed in ewes with differing ovulation rates. Expression of mRNA for CARTPT, as well as LHCGR, FSHR, CYP19A1 and CYP17A1 was determined in antral follicles $\geq 1 \mathrm{~mm}$ in diameter collected during the follicular phase in ewes heterozygous for the Booroola and Inverdale genes (I+B+; average ovulation rate 4$)$ and ++ contemporaries (++; average ovulation rate 1.8). In ++ ewes $(n=6)$, CARTPT was expressed in small follicles ( 1 to $<3 \mathrm{~mm}$ diameter), where $18.8 \pm 2.5 \%$ follicles expressed CARTPT. CART peptide was also detected in follicular fluid of some follicles of ++ ewes. In I+B+ ewes, $5 / 6$ ewes did not have any follicles that expressed CARTPT, and no CART peptide was detected in any follicle examined. Expression pattern of CYP19A1 differed between I+B+ and ++ ewes with an increased percentage of small and medium follicles ( 3 to $<4.5 \mathrm{~mm}$ diameter) but decreased percentage of large follicles $(\geq 4.5 \mathrm{~mm}$ diameter) expressing CYP19A1 in the $\mathrm{I}+\mathrm{B}+$ ewes. Many of the large follicles from the $\mathrm{I}+\mathrm{B}+$ ewes appeared non-functional and expression of LHCGR, FSHR, CYP17A1 and CYP19A1 was less than that observed in ++ ewes. Expression of FSHR and CYP17A1 was not different between groups in small and medium follicles, but $L H C G R$ expression was approximately double in I+B+ewes compared to that in ++ ewes. Thus, ewes with high ovulation rates had a distinct pattern of expression of CARTPT mRNA and protein compared to ewes with normal ovulation rates, providing evidence for CART being important in the regulation of ovulation rate.
\end{abstract}

Reproduction (2017) 153 471-479

\section{Introduction}

The number of follicles that develop for ovulation each reproductive cycle (i.e. ovulation rate) is a key determinant of fecundity. Ovulation rate varies considerably among mammalian species from those that predominately ovulate a single ova and thus have one offspring at a time such as humans and cattle to those that ovulate many ova at each reproductive cycle and thus have litters, such as pigs, mice and dogs. Although sheep are predominately a low ovulation rate species, ovulating one or two ova at each reproductive cycle, there is considerable plasticity in ovulation rate in sheep with some sheep ovulating over 10 ova at a reproductive cycle (Juengel et al. 2013). Factors such as nutrition, body size and genetics are known to influence ovulation rate in sheep (Scaramuzzi et al. 2011, Shorten et al. 2013).

Previous studies of the control of ovulation rate have focused on the role of gonadotropins from the pituitary gland (i.e. follicle-stimulating hormone (FSH) and luteinising hormone $(\mathrm{LH})$ ) because they are known to be critical for development of the ovarian follicles for ovulation (Webb \& Campbell 2007, Mihm \& Evans 2008). The gonadotropins stimulate the growth of follicles and administering exogenous FSH can override the natural limitations on the number of ovulating follicles. This forms the basis for fertility treatments in livestock species (Barros et al. 2010, Menchaca et al. 2010) as well as humans (van Wely et al. 2011). Although ovulation rate has traditionally been thought to be controlled by the pituitary gland, increasing evidence points to local ovarian factors as key physiological regulators of ovulation rate (Gilchrist et al. 2004, Juengel \& McNatty 2005, Silva et al. 2009). A search for novel ovarian factors that regulate fertility identified cocaineand amphetamine-regulated transcript (CARTPT) as such a factor (Kobayashi et al. 2004, Yao et al. 2004). CART (the biologically active mature CARTPT peptide) was first identified as a neuropeptide with known roles in controlling body weight and reward response (Rogge et al. 2008). In contrast to the stimulatory role of the gonadotropins, CART appears to act as a suppressor of follicular growth, being actively expressed in follicles 
undergoing atresia (i.e. dying) that will not go on to ovulate (Smith et al. 2011).

In cattle ovaries, CARTPT is expressed in both the oocyte and the supporting somatic cells (granulosa cells) of the follicle and regulates the production of oestradiol (Kobayashi et al. 2004, 2006), a key hormone involved in the timing of ovulation and receptivity of the female to the male (Fabre-Nys \& Martin 1991, Christian \& Moenter 2010, Flanagan-Cato 2011). Further, CARTPT is not expressed in the adult ovary in litter-bearing species, suggesting that this pathway is not active in animals with a high ovulation rate phenotype (Smith et al. 2011). Thus, the aim of the present study was to determine the expression pattern of CARTPT mRNA in antral follicles during selection of the ovulatory follicle and determine if the pattern of expression differs between sheep with a low or high ovulation rate phenotype. Furthermore, given the known interactions between CART and oestradiol synthesis and the responsiveness of follicles to gonadotropins, expression of mRNA encoding $L H C G R$, FSHR, CYP17A1 and CYP19A1 was also determined for these follicles.

\section{Materials and methods}

\section{Animals}

Ewes were sourced from the Invermay farm, and the experiment was approved by the Invermay Agricultural Centre's Animal Ethics Committee and followed the 1999 Animal Protection (Codes of Ethical Conduct) Regulations of New Zealand. All ewes were approximately 5.5 years old and were pasture-fed (grass) to meet the nutritional requirements and had free access to water. High ovulation rate ewes $(\mathrm{I}+\mathrm{B}+)$, with a single copy of the Booroola mutation $(\mathrm{FeCB})$ and the Inverdale mutation $\left(F e c X^{\prime}\right)$ were identified through genotyping (GenomNZ, Mosgiel, New Zealand). On average, ovulation rate of $\mathrm{I}+\mathrm{B}+$ ewes is $258 \%$ that of ++ sheep (Juengel et al. 2013). Control $(++)$ ewes were from a similar genetic background but did not carry either the Booroola or Inverdale mutations. The weight of the ewes was similar $(64.5 \pm 2.5 \mathrm{~kg}$ and $64.0 \pm 1.7 \mathrm{~kg}$ for control and $\mathrm{I}+\mathrm{B}+$ ewes respectively). The study was performed during the natural breeding season.

\section{Sample collection}

Ewes ( $n=6$ in each group) were presynchronised using controlled internal drug-release devices (CIDR-G; SVS Veterinary Supplies Ltd; Christchurch, New Zealand) administration for 13 days. After the removal of the CIDR, timing of onset of oestrus was determined by marking by a harnessed vasectomised ram with crayon marks evaluated approximately every $12 \mathrm{~h}$. Prostaglandin $\mathrm{F}_{2 \alpha}$ analogue (PGF; $0.7 \mathrm{~mL}$ of Estrumate, active ingredient cloprostenol, SVS Veterinary Supplies Ltd) was given on days 5-6 of the subsequent oestrous cycle to induce the follicular phase and selection of preovulatory follicles. Ewes were killed by captive bolt and then exsanguinated $12 \mathrm{~h}$ after PGF injection.
Ovaries were collected, and all follicles $\geq 1 \mathrm{~mm}$ in diameter were dissected out of the ovaries, and follicular fluid was collected from follicles $>2 \mathrm{~mm}$ in diameter. After the addition of a protease inhibitor (Roche complete Mini Protease Inhibitor Cocktail Tablets; Sigma-Aldrich), follicular fluid was frozen on dry ice, whereas follicles were frozen in liquid nitrogen and both were stored at $-70^{\circ} \mathrm{C}$ until further processing. A blood sample was collected by venipuncture from each ewe every $6 \mathrm{~h}$ for the $48 \mathrm{~h}$ preceding tissue collection. Plasma was collected from this sample and stored at $-20^{\circ} \mathrm{C}$ until assayed.

\section{Analysis of FSH and progesterone in plasma}

Concentrations of FSH were measured in all plasma samples in a single RIA (McLeod et al. 1997) using reagents provided by the National Institute of Diabetes and Digestive and Kidney Diseases (NIDDK; Bethesda, MD, USA). The sensitivity of the assay, defined as the lowest point on the standard curve, was $0.4 \mathrm{ng} / \mathrm{mL}$ and the coefficient of variation (CV) of 5 quality control pool samples with between 1 and $5 \mathrm{ng} / \mathrm{mL}$ FSH was $<10 \%$. Concentrations of progesterone were measured using a coat-a-count kit RIA (CAC kit, Siemens Healthcare Diagnostics) in the plasma sample collected at the time of administration of PGF and at tissue collection. The sensitivity of the assay, defined as the lowest point on the standard curve, was $0.08 \mathrm{ng} / \mathrm{mL}$, and the CV of 3 quality control pool samples between 2 and $8 \mathrm{ng} / \mathrm{mL}$ was $<5 \%$. For the $\mathrm{FSH}$ and progesterone assay, no samples were below the sensitivity of the assay.

\section{Measurement of mRNA encoding CARTPT, LHCGR, FSHR, CYP19A1 and CYP17A1}

The follicles were homogenised in TRIzol (Invitrogen, Life Technologies) using a Geno/Grinder 2010 (SPEX SamplePrep; Total Lab Systems Ltd, Auckland, New Zealand). Total cellular RNA was purified according to the manufacturer's protocol using the PureLink Pro 96 total RNA Purification Kit (Invitrogen, Life Technologies). Total cellular RNA (500 ng) was DNase I treated prior to cDNA synthesis using Superscript III (Life Technologies) according to the manufacturer's instructions. Three multiplexes were designed using Beacon Designer v8; RPL19/CART, RPL19/FSHR/LHCGR and RPL19/CYP17A1/CYP19A1 (Table 1). Primers were purchased from Integrated DNA Technologies (Singapore), and the duallabelled TaqMan probes were purchased from Sigma-Aldrich. Identity of amplified products was confirmed by sequencing (Waikato DNA Sequencing Facility, Hamilton, New Zealand). The sensitivity of the assay was optimised with a primer matrix approach for all genes using SYBR Green (Invitrogen, Life Technologies). The absence of non-specific products was assessed by dissociation curve analysis.

The concentration of the probe was optimised for all genes and assessed in the multiplex to confirm that the $\mathrm{Ct}$ values were not affected by multiplexing. For the RPL19/CART multiplex, there was a complete inhibition of CARTPT gene amplification; therefore, concentrations of CARTPT mRNA were measured using a SYBR Green method. Efficiency and range of each assay was calculated using serial dilutions of a standard sample (Table 2). Samples outside the range were 


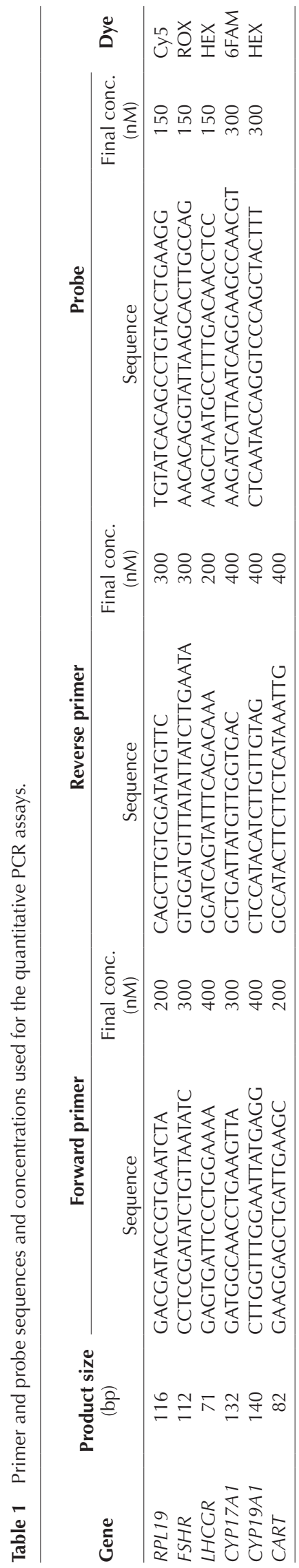

Table 2 Characteristics of the quantitative PCR assays.

\begin{tabular}{lccc}
\hline Gene & Efficiency $(\%)$ & $\boldsymbol{R}^{\mathbf{2}}$ & Range $($ cycles) \\
\hline RPL19 & 98.6 & 1.000 & $22.03-30.12$ \\
CART & 99.0 & 0.988 & $25.35-33.50$ \\
RPL19 & 98.8 & 0.989 & $20.79-30.27$ \\
FSHR & 99.7 & 0.995 & $23.71-32.95$ \\
LHCGR & 98.8 & 0.990 & $23.08-31.91$ \\
RPL19 & 100.0 & 0.988 & $19.11-30.20$ \\
CYP17A1 & 99.7 & 0.992 & $21.64-32.70$ \\
CYP19A1 & 99.7 & 0.987 & $20.40-31.26$ \\
\hline
\end{tabular}

either repeated with a more dilute sample (those with Ct less than the lowest acceptable $\mathrm{Ct}$ ) or were considered below the sensitivity of the assay (those with $\mathrm{Ct}$ greater than the highest acceptable $\mathrm{Ct}$ ). All samples were run in duplicate with average $\mathrm{Ct}$ used for calculations. The average $\mathrm{Ct}$ for the reference gene, RPL19, did not differ between the two genotypes (i.e., I+B+ and ++ animals). A calibrator sample was run on every plate and was used to calculate the $\Delta \Delta \mathrm{Ct}$ for each sample. Negative controls included no template reactions and samples that omitted the reverse transcriptase for cDNA synthesis. These controls gave the expected negative results for all assays.

\section{Analysis of CART in follicular fluid}

Concentrations of CART protein were measured in follicular fluid using a RIA (Phoenix Pharmaceuticals, Inc, Burlingame, CA, USA). This assay, which has $100 \%$ cross-reactivity with bovine CART (amino acids 42-89), has been validated for use with bovine follicular fluid (Kobayashi et al. 2004), and bovine and ovine CART are identical in this region. Very limited amounts of follicular fluid were available from the small follicles and thus the follicular fluid was diluted with assay buffer before being assayed. Sensitivity of the assay was 0.25 $0.5 \mathrm{ng} / \mathrm{mL}$ (depending on the dilution of the follicular fluid used), and coefficients of variation for two standard samples at approximately 20 and $75 \%$ binding were $<15 \%$.

\section{Statistical analysis}

Statistical analysis was undertaken using GENSTAT, version 15 (VSN International, Hemel Hempstead, UK). Total ovarian weight, the number of $\mathrm{CL}$, average weight of $\mathrm{CL}$ and total $\mathrm{CL}$ weight were examined using analysis of variance. The numbers of follicles classified as small ( 1 to $<3.0 \mathrm{~mm}$ in diameter), medium (3 to $<4.5 \mathrm{~mm}$ in diameter) and large $(\geq 4.5 \mathrm{~mm}$ in diameter) as well as total number of follicles $\geq 1 \mathrm{~mm}$ in diameter were transformed (In for large and total, In(number+1) for small and medium as some animals had no follicles of this size) prior to examination by analysis of variance. Concentrations of $\mathrm{FSH}$ and progesterone in plasma were analysed using REML taking into account the repeated nature of the samples. An autoregressive structure $(A R(1))$ was used for FSH concentrations with a uniform structure used for progesterone analysis. For analysis of mRNAs of interest, follicles were classified into one of the three categories: small, medium or large. These size classes were chosen to represent follicles that were gonadotropin responsive but not yet gonadotropin dependent (small), gonadotropin dependent 
(medium) and forming the presumptive preovulatory pool (large). Proportion of follicles at each size class expressing the mRNA was compared between genotypes using GLIM with binomial distribution and a logit link. Fold-difference of mRNA concentrations was examined using REML including genotype, follicle size and genotype by follicle size interactions as fixed effects with animal as a random factor. For CYP17A1, LHCGR and FSHR mRNA, values below the detection limit of the assay were included as 0 . Data were transformed (natural $\log$ (fold-difference +1 ), to allow for inclusions of 0 values) prior to analysis for normalisation. For CYP19A1 mRNA, analysis of fold-differences was limited to those follicles expressing CYP19A1 mRNA given that a high proportion of follicles did not have detectable CYP19A1 mRNA. Data were transformed (natural $\log$ (fold-difference)) prior to analysis for normalisation. For all mRNAs, a significant follicle size by genotype interaction was observed $(P<0.001)$, and thus, difference between genotypes were analysed for each follicle size. Differences in expression of CYP17A1, LHCGR and FSHR mRNA between CARTPT-positive and -negative follicles of the ++ animals were analysed using REML with animal as a random factor. Data presented are the geometric means and $95 \%$ confidence limits of the back transformed data unless otherwise stated.

\section{Results}

\section{Ovarian and endocrine characteristics}

Total ovarian weight was not different between genotypes $(P=0.129$; Table 3$)$. The total number of follicles were decreased $(P=0.004)$ in the $\mathrm{I}+\mathrm{B}+$ ewes compared to the ++ ewes. This was the result of a decreased $(P=0.004)$ number of small follicles, with no differences observed in the number medium or large follicles (Table 3). When compared to ++ ewes, the $\mathrm{I}+\mathrm{B}+$ ewes had an increased $(P=0.008)$ number of $\mathrm{CL}$ with each $\mathrm{CL}$ weighing less $(P<0.001)$, resulting in no observed differences $(P=0.144)$ in total $\mathrm{CL}$ weight (Table 3).

Concentrations of $\mathrm{FSH}$ were increased $(P<0.001)$ in the $\mathrm{I}+\mathrm{B}+$ compared to the ++ animals (Table 3 ).
Sampling time did not affect the concentrations of FSH in plasma $(P=0.113)$; thus, there was no evidence of a sustained decrease in FSH concentrations, as would be expected if dominant follicles were present on the ovary prior to the initiation of the follicular phase. Concentrations of progesterone in plasma were similar between genotypes both before and $12 \mathrm{~h}$ after the initiation of the follicular phase (Table 3). As expected, concentrations of progesterone were decreased $12 \mathrm{~h}$ after prostaglandin administration $(P<0.001)$, with progesterone concentrations decreasing by at least $60 \%$ in all animals, indicating that administration of PGF had induced luteal regression in all animals.

\section{Pattern of expression of mRNA encoding CARTPT, LHCGR, FSHR, CYP19A and CYP17A in follicles}

\section{CARTPT}

The majority of follicles did not contain detectable amounts of CARTPT mRNA. The CARTPT mRNA was predominately expressed by small follicles in the ++ animals, where all animals had some follicles expressing CARTPT mRNA with an average of $18.8 \pm 2.5 \%$ (range $13-22 \%$ ) of follicles positive for CARTPT in this size class (Fig. 1). In the I+B+ animals, from the 113 follicles in which RNA extraction was successful, expression of CARTPT was limited to two large follicles collected from a single animal (Fig. 1). No small follicles expressed CARTPT from this genotype. In no instance was a follicle that was positive for CARTPT also positive for CYP19A1 mRNA expression.

\section{LHCGR and FSHR}

Most follicles in all size classes expressed mRNA for both the LHCGR and the FSHR with no differences in proportion of follicles expressing either mRNA between genotypes for small and medium follicles. There was a decreased $(P<0.05)$ percentage of large follicles in the $\mathrm{I}+\mathrm{B}+$ animals expressing FSHR and LHCGR mRNA, whereas all large follicles expressed both mRNAs in the

Table 3 Ovarian and endocrinological characteristics of ewes.

\begin{tabular}{|c|c|c|c|c|}
\hline \multirow[b]{2}{*}{ Characteristic } & \multicolumn{2}{|c|}{ Genotype } & \multirow[b]{2}{*}{ Pooled S.E.M. } & \multirow[b]{2}{*}{$\boldsymbol{P}$ value $(++$ vs $\mathrm{I}+\mathrm{B}+)$} \\
\hline & ++ & $\mathrm{I}+\mathrm{B}+$ & & \\
\hline Total ovarian weight $(\mathrm{g})$ & 3.73 & 2.92 & 0.35 & 0.129 \\
\hline Ln(total number of follicles $\geq 1 \mathrm{~mm}$ ) & 3.83 & 2.86 & 0.26 & 0.004 \\
\hline $\operatorname{Ln}($ number of small follicles $(1$ to $<3 \mathrm{~mm}))$ & 3.69 & 2.40 & 0.34 & 0.004 \\
\hline $\operatorname{Ln}(($ number of medium follicles $(3$ to $<4.5 \mathrm{~mm}))+1)$ & 1.35 & 1.42 & 0.40 & 0.854 \\
\hline $\operatorname{Ln}(($ number of large follicles $(\geq 4.5 \mathrm{~mm}))+1)$ & 1.22 & 0.88 & 0.35 & 0.349 \\
\hline Number of $\mathrm{CL}$ & 1.8 & 4.0 & 0.5 & 0.008 \\
\hline Ave weight of CL (g) & 0.53 & 0.17 & 0.05 & $<0.001$ \\
\hline Total CL weight (g) & 0.94 & 0.63 & 0.14 & 0.144 \\
\hline Average $\mathrm{FSH}(\mathrm{ng} / \mathrm{mL})$ & 1.11 & 2.98 & 0.30 & $<0.001$ \\
\hline $\mathrm{P} 4$ at $\mathrm{PGF}(\mathrm{ng} / \mathrm{mL})$ & 2.87 & 2.75 & & \\
\hline $\mathrm{P} 4$ at tissue collection $(\mathrm{ng} / \mathrm{mL})$ & 0.82 & 0.82 & 0.34 & 0.49 \\
\hline
\end{tabular}

$\mathrm{P} 4$, progesterone. 


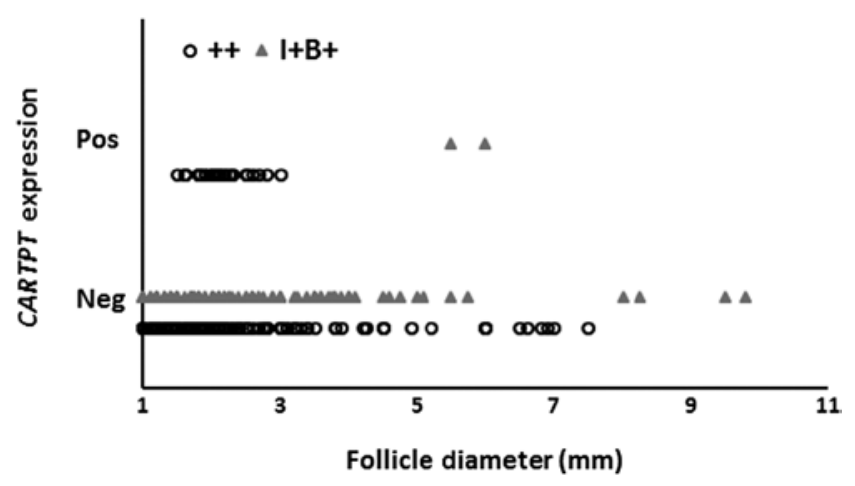

Figure 1 Size distribution of follicles negative (Neg) or positive (Pos) for CARTPT mRNA expression in ++ and $\mathrm{I}+\mathrm{B}+$ ewes.

++ animals, an on average $77 \pm 7 \%$ expressed $F S H R$ and $92 \pm 3 \%$ expressed $L H C G R$ in the $\mathrm{I}+\mathrm{B}+$ animals.

When examining the level of expression, no differences were observed between genotypes for small and medium follicles for FSHR mRNA expression (Fig. 2). Expression of LHCGR mRNA was increased approximately 2 -fold in small and medium follicles of $\mathrm{I}+\mathrm{B}+$ animals compared to ++ animals. In contrast, large follicles of $\mathrm{I}+\mathrm{B}+$ animals had decreased concentrations of both FSHR and LHCGR compared to large follicles from ++ animals (Fig. 2).

\section{CYP17A1 and CYP19A1}

Most small and medium follicles were positive for expression of CYP17A1 with no differences observed in the average proportion of follicles expressing CYP17A1 between genotypes in these classes. In ++ animals, all large follicles expressed CYP17A1, whereas on average, only $54 \pm 9 \%$ of large follicles expressed CYP17A 1 mRNA in the $\mathrm{I}+\mathrm{B}+$ animals $(P<0.001)$.

In ++ animals, CYP19A1 mRNA was expressed in a few small follicles, with increased expression in medium follicles, and the majority of large follicles expressed CYP19A1 mRNA (Fig. 3). The pattern of expression was very different in the $\mathrm{I}+\mathrm{B}+$ animals, with a greater percentage of small and medium follicles expressing CYP19A1 mRNA than ++ animals. The majority of the medium follicles expressed CYP19A1 mRNA, but relatively fewer of the large follicles expressed CYP19A1 when compared to ++ follicles (Fig. 3).

Of those follicles expressing CYP19A1 mRNA, expression was increased in small follicles and tended to be increased in medium follicles collected from $\mathrm{I}+\mathrm{B}+$ animals compared to those from ++ animals (Fig. 2). Expression of CYP17A1 mRNA also tended to be increased in small follicles of $\mathrm{I}+\mathrm{B}+$ ewes (Fig. 2). For large follicles, expression of both CYP17A1 and CYP19A1 mRNA was decreased in $\mathrm{I}+\mathrm{B}+$ compared to ++ animals (Fig. 2).

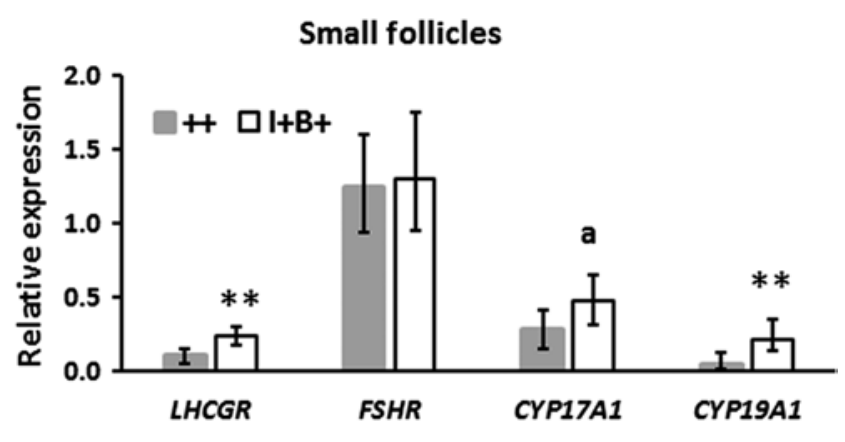

Medium follicles
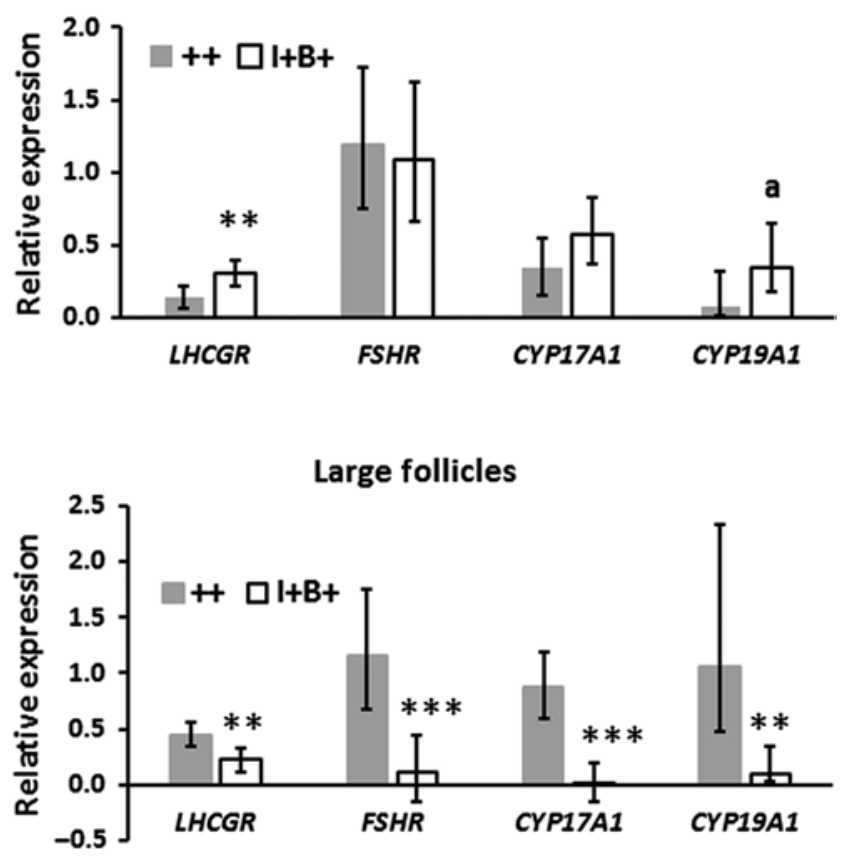

Figure 2 Expression of mRNA encoding LHCGR, FSHR, CYP17A1 and CYP19A1 in small ( 1 to $<3 \mathrm{~mm}$ in diameter, top panel), medium ( 3 to $<4.5 \mathrm{~mm}$ in diameter, middle panel) and large $(\geq 4.5 \mathrm{~mm}$ in diameter, bottom panel) ovarian follicles from ++ and I+B+ ewes. Values are geometric means and $95 \%$ confidence intervals. $\mathrm{I}+\mathrm{B}+$ different to ++ indicated by ${ }^{* *} P<0.01,{ }^{* * *} P<0.001$ or ${ }^{a} P<0.1$.

\section{Characterisations of FSHR, LHCGR and CYP17A1 $m R N A$ in CARTPT-positive and-negative follicles}

To further characterise the potential interactions between CARTPT expression and gonadotropin responsiveness and steroid production, relative expression of FSHR, LHCGR and CYP17A1 mRNAs were compared between small follicles that were positive or negative for CARTPT mRNA in the ++ control ewes. Concentrations of FSHR mRNA were increased in CARTPT-positive follicles compared to those in CARTPT negative follicles, with no differences observed in LHCGR or CYP17A1 mRNA (Fig. 4). 


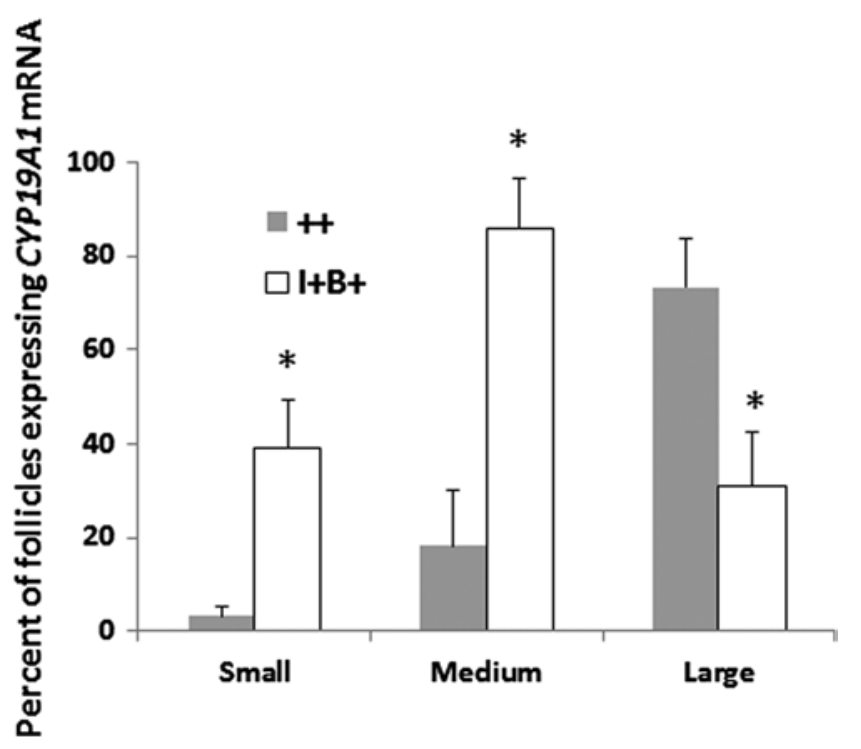

Figure 3 Percentage (mean \pm S.E.M.) of follicles in each size class expressing CYP19A1 mRNA in small ( 1 to $<3 \mathrm{~mm}$ in diameter), medium ( 3 to $<4.5 \mathrm{~mm}$ in diameter) and large $(\geq 4.5 \mathrm{~mm}$ in diameter) follicles from ++ and $\mathrm{I}+\mathrm{B}+$ ewes. ${ }^{*}$ Expression in $\mathrm{I}+\mathrm{B}+$ follicles is different $(P<0.01)$ than expression in ++ follicles.

\section{Concentrations of CART peptide in follicular fluid}

Only 11 of 113 follicles examined had detectible amounts of CART peptide in their follicular fluid. Detection of CART peptide in the follicular fluid was limited by the amount of follicular fluid available for analysis in the small follicles as only 4/12 follicles with detectible expression of CARTPT mRNA had detective CART peptide in their follicular fluid. The follicular fluid containing CART peptide was from follicles from the ++ ewes and ranged in size from 2.2 to $3.1 \mathrm{~mm}$ in diameter. These included follicles that were positive for CARTPT $m R N A$ as well as some that were negative. No follicles $(0 / 43)$ from the I+B+ ewes had detectible CART peptide in their follicular fluid. No follicle $(0 / 48)$ that

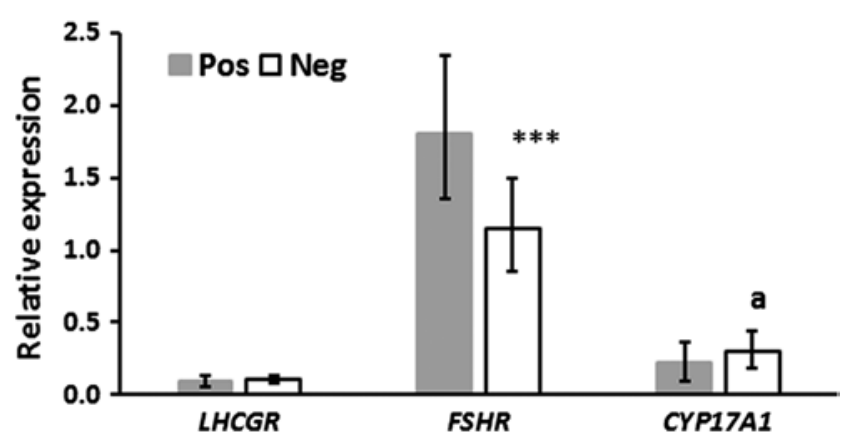

Figure 4 Relative expression of mRNA (geometric mean and 95\% confidence intervals) encoding $L H C G R$, FSHR and CYP17A1 in CARTPT-positive (Pos) or CARTPT-negative ( $\mathrm{Neg}$ ) small follicles ( 1 to $<3 \mathrm{~mm}$ in diameter) from ++ sheep. Expression in CARTPTnegative follicles different than CARTPT-positive follicles are indicated by $* * * P<0.001$ or ${ }^{\text {a }} P<0.1$. expressed CYP19A1 mRNA had detectible amounts of CART peptide.

\section{Discussion}

In the ++ sheep, CARTPT mRNA expression was only observed in follicles $<3 \mathrm{~mm}$ in diameter and only in approximately $20 \%$ of the follicles in that class range. One previous study examining CARTPT expression in sheep follicles collected from the slaughterhouse observed some expression in follicles greater than $3 \mathrm{~mm}$ in diameter (smallest size examined), with the level of expression decreasing as follicle size increased (Huang et al. 2016). The differences between these studies are unclear but could be related to the sensitivity of the assays, breed of sheep (genetics), timing of follicular collection or nutritional status of the sheep. However, taking the results together, it appears that CARTPT mRNA decreases as the follicle matures such that the highest expression is in follicles less than $3 \mathrm{~mm}$ in diameter, which are gonadotropin responsive but not dependent.

In cattle and sheep, treatment of granulosa cell cultures with CART caused decreased production of oestradiol (Kobayashi et al. 2006, Huang et al. 2016), which in cattle has been linked to a decrease in expression of CYP19A1 mRNA (Sen et al. 2007). Furthermore, injection of CART into the follicular fluid of dominant follicles reduces oestradiol secretion and CYP19A1 mRNA concentrations, leading to the hypothesis that CART is an important regulator of oestradiol secretion in cattle (Lv et al. 2009). The timing of expression of CARTPT during the development of sheep follicles does not support the regulation of oestradiol synthesis as a major direct function of CART in sheep as no follicles were observed that expressed both CYP19A1 mRNA and CARTPT mRNA/CART peptide. However, it is possible that expression of CARTPT/CART peptide prevents the follicles from being able to express CYP19A1. Given the known role of oestrogens in stimulating granulosa cell proliferation and preventing atresia (Quirk et al. 2004), expression of CARTPT could target a follicle for an atretic pathway. Furthermore, lack of expression of CARTPT in the $\mathrm{I}+\mathrm{B}+$ follicles could underlie a reduced level of atresia in these animals thus allowing more ovulatory follicles to develop and increasing ovulation rate. However, it is unclear if atresia rates are supressed in ewes with the Booroola or Inverdale genes, with some studies failing to find differences in the overall rates of atresia (McNatty et al. 1985, Shackell et al. 1993) and others finding differences in the pattern of atresia and level of atresia in specific follicular size classes (Driancourt et al. 1985, Mandiki et al. 2000). However, it should be noted that the timing of the majority of follicle loss by atresia is typically earlier in the development of ovarian follicles in sheep, with greater 
than $85 \%$ of follicles classified as early atretic being $<1.6 \mathrm{~mm}$ in diameter in Merino ewes (Driancourt et al. 1985). Thus, if CART is affecting atresia, it may be targeting follicles later in the development, potentially influencing the pool of follicles available for selection for ovulation. In support of this, the rate of atresia in large $(>5.0 \mathrm{~mm}$ where average size of $\mathrm{B}+$ ovulatory follicles was $5.7 \mathrm{~mm}$ ), but not small or medium, follicles of ewes carrying a single copy of the Booroola gene was reduced compared to ++ controls (Mandiki et al. 2000). Although CARTPT expression occurs prior to this, it is possible that the expression of CARTPT prevents the expression of aromatase and production of oestradiol, leading to atresia at a later stage of development.

Surprisingly, expression of FSHR mRNA was increased in small follicles expressing CARTPT mRNA compared to those not expressing CARTPT. This observation is inconsistent with previous observations in bovine granulosa cells where FSH suppresses CARTPT mRNA expression and CART suppresses FSH signalling (Sen et al. 2007, 2008, Lv et al. 2009). Similarly, in ovine granulosa cells, FSH stimulated cell proliferation in long-term cultures (7 days), but inclusion of CART in the media blocked this stimulation (Huang et al. 2016). Additionally, in cattle, expression of CARTPT mRNA is increased in atretic antral follicles when compared to that in healthy antral follicles (Smith et al. 2011). However, in sheep, even very atretic follicles continue to expresses FSHR mRNA (Tisdall et al. 1995), and thus, potentially, the ability of CART to suppress FSH actions in ovine granulosa cells occurs at a point distal to FSHR mRNA expression.

Interestingly, most animals with high ovulation rate had no detectible expression of CARTPT mRNA in follicles $\geq 1 \mathrm{~mm}$, with no animal having any follicles positive for CART protein. This contrasts to what was observed in the ++ ewes, where CARTPT mRNA was observed in follicles $1-3 \mathrm{~mm}$ in diameter for all animals and most animals had follicles with detectible CART peptide in the follicular fluid of at least one follicle of this size class. Thus, altered expression of CARTPT mRNA was associated with increased ovulation rates.

It is also important to note that follicles mature at a smaller size in both Booroola and Inverdale ewes. For instance, the average size of the preovulatory follicle is smaller (McNatty et al. 1985, Shackell et al. 1993) and oocytes exit their more rapid growth phase earlier, at a follicular diameter of $0.24 \mathrm{~mm}$ in BB ewes compared to that of $0.38 \mathrm{~mm}$ in ++ ewes (Wilson et al. 2001). Thus, follicles of similar size may not represent follicles of similar maturity when comparing ++ to I+B+ ewes (Juengel et al. 2013), and this could underlie the observed differences in expression in CARTPT mRNA and CART peptide, with the potential that follicles $<1 \mathrm{~mm}$ in diameter express CARTPT mRNA in $\mathrm{I}+\mathrm{B}+$ ewes. However, the expression of CARTPT mRNA and CART peptide was not observed in the ++ ewes until follicles reached a diameter of at least $1.5 \mathrm{~mm}$ and continued to be observed in follicles until they were $3 \mathrm{~mm}$ in diameter. Thus, it is likely that some of the $\mathrm{I}+\mathrm{B}+$ follicles examined would be of similar maturity of the follicles expressing CARTPT/CART peptide in the ++ ewes.

Whether altering activities of either BMP15 or the BMP signalling pathway might directly alter CARTPT expression in the $\mathrm{I}+\mathrm{B}+$ ewes is unknown. BMP15 is known to be produced from the oocyte of type 2 (primary) and larger follicles with expression increasing during preantral follicle development (Feary et al. 2007). Additionally, granulosa and theca cells both produce mRNA encoding BMPR1B and BMPR2 (Feary et al. 2007), the proposed receptors for BMP15 (Juengel et al. 2013). In cattle, addition of CART to the media was able to suppress BMP2-stimulated oestradiol production (Selvaraju et al. 2013), indicating a potential interaction between these pathways.

CART has known roles in regulating the body weight (Rogge et al. 2008), and in the mouse pituitary, restricted feeding leads to an upregulation of Cartpt mRNA (Burgos et al. 2016) providing evidence that in some tissues, poor nutrition would result in increases of Cartpt mRNA. In sheep, it is well known that providing an increasing level of nutrition just before breeding results in an increased number of lambs born through increased ovulation rates (Scaramuzzi et al. 2006). Potentially, nutritional suppression of CARTPT in granulosa cells could be a pathway for nutritional increases in ovulation rate in sheep, but this hypothesis remains to be tested. Interestingly, we have previously shown that ewes heterozygous for the Inverdale mutation (i.e. I+) have an increased sensitivity to nutritional regulation of ovulation rate (Demmers et al. 2011). Similar increased sensitivity to nutritional regulation of ovulation rate has been observed in Booroola ewes (Landau et al. 1995), although this effect has not always been apparent (Montgomery et al. 1983). Further investigation into the potential role of CART in regulating the nutritional control of ovulation rate in sheep seems warranted.

Concentrations of FSH were also higher in the $\mathrm{I}+\mathrm{B}+$ animals. Although previous studies in Inverdale and Booroola animals have reported variable results regarding $\mathrm{FSH}$ concentrations with some studies showing no differences between ++ and Booroola ewes (Driancourt et al. 1991, Souza et al. 1997), previous studies with New Zealand-sourced Booroola sheep have shown consistently increased FSH concentrations (McNatty et al. 1987, 1989, 1994, Phillips et al. 1993). Given that FSH is known to suppress CARTPT mRNA, increased FSH concentrations could be suppressing the expression of CARTPT to non-detectable levels in these animals, thus altering the number of follicles available for the selection for ovulation.

Previous studies have shown that ewes carrying either the Inverdale or Booroola gene have follicles 
that mature at a smaller size (Juengel et al. 2013). This is linked to earlier responsiveness to $\mathrm{LH}$, but not FSH, in the granulosa cells of these follicles (McNatty et al. 2009, Crawford et al. 2011). The increased expression of mRNA for $L H C G R$, but not FSHR, in small and medium follicles is consistent with these findings. Additionally, the differing pattern of CYP19A1 mRNA expression is also consistent with follicles maturing at a smaller size. The observation of large follicles in the $\mathrm{I}+\mathrm{B}+$ animals was somewhat unexpected as ewes homozygous for the Booroola mutation typically have very few, if any, follicles in this size class. However, most of these follicles expressed little or no mRNA encoding FSHR, CYP17A1 or CYP19A1, indicating that they were likely cystic and not functional.

In conclusion, in ++ ewes, CARTPT mRNA was expressed in approximately $20 \%$ of ovine follicles from 1 to $3 \mathrm{~mm}$ in diameter, and CART peptide was also observed in the follicular fluid of some of the follicles. No follicles expressed both CARTPT (mRNA or peptide) and CYP19A1 mRNA; therefore, the role of CART in sheep may differ to that observed in cattle, where a key role of CART appears to be the suppression of oestradiol synthesis in subordinate follicles during the selection of the dominant follicle. Most animals with high ovulation rates had non-detectable levels of CARTPT mRNA in any follicle $\geq 1 \mathrm{~mm}$ in diameter, and CART peptide was not observed in the fluid of any follicle examined in these animals. Thus, CARTPT mRNA/CART peptide expression may be an important regulator of the number of follicles selected for ovulation in sheep.

\section{Declaration of interest}

The authors declare that there is no conflict of interest that could be perceived as prejudicing the impartiality of the research reported.

\section{Funding}

This work was funded by the Marsden Fund (The Royal Society of New Zealand; contract ARG1101).

\section{Acknowledgements}

The authors would like to acknowledge the members of the Invermay Reproduction Team and Invermay farm staff for help with animal care and sample collection. The authors would also like to thank Shirley Martin for determining the concentrations of FSH in plasma samples.

\section{References}

Barros CM, Ereno RL, Simoes RA, Fernandes P, Buratini J \& Nogueira MF 2010 Use of knowledge regarding $\mathrm{LH}$ receptors to improve superstimulatory treatments in cattle. Reproduction, Fertility, and Development 22 132-137. (doi:10.1071/RD09227)
Burgos JR, Iresjo BM \& Smedh U 2016 MCG101-induced cancer anorexiacachexia features altered expression of hypothalamic Nucb2 and Cartpt and increased plasma levels of cocaine- and amphetamine-regulated transcript peptides. Oncology Reports 35 2425-2430. (doi:10.3892/ or.2016.4558)

Christian CA \& Moenter SM 2010 The neurobiology of preovulatory and estradiol-induced gonadotropin-releasing hormone surges. Endocrine Reviews 31 544-577. (doi:10.1210/er.2009-0023)

Crawford JL, Heath DA, Reader KL, Quirke LD, Hudson NL, Juengel JL \& McNatty KP 2011 Oocytes in sheep homozygous for a mutation in bone morphogenetic protein receptor $1 \mathrm{~B}$ express lower mRNA levels of bone morphogenetic protein 15 but not growth differentiation factor 9 . Reproduction 142 53-61. (doi:10.1530/REP-10-0485)

Demmers KJ, Smaill B, Davis GH, Dodds KG \& Juengel JL 2011 Heterozygous Inverdale ewes show increased ovulation rate sensitivity to pre-mating nutrition. Reproduction, Fertility, and Development 23 866-875. (doi:10.1071/RD10344)

Driancourt MA, Cahill LP \& Bindon BM 1985 Ovarian follicular populations and preovulatory enlargement in Booroola and control Merino ewes. Journal of Reproduction and Fertility 73 93-107. (doi:10.1530/jrf.0.0730093)

Driancourt MA, Bodin L \& Fry RC 1991 FSH secretion, its regulation and its relationship with ovulation rate in a range of prolific and non prolific breeds of sheep. In Major Genes for Reproduction in Sheep, pp 125134. INRA: Paris, France.

Fabre-Nys C \& Martin GB 1991 Hormonal control of proceptive and receptive sexual behavior and the preovulatory $\mathrm{LH}$ surge in the ewe: reassessment of the respective roles of estradiol, testosterone, and progesterone. Hormones and Behavior 25 295-312. (doi:10.1016/0018506X(91)90003-Z)

Feary ES, Juengel JL, Smith P, French MC, $\mathrm{O}^{\prime}$ Connell AR, Lawrence SB, Galloway SM, Davis GH \& McNatty KP 2007 Patterns of expression of messenger RNAs encoding GDF9, BMP15, TGFBR1, BMPR1B, and BMPR2 during follicular development and characterization of ovarian follicular populations in ewes carrying the Woodlands FecX2W mutation. Biology of Reproduction 77 990-998. (doi:10.1095/ biolreprod.107.062752)

Flanagan-Cato LM 2011 Sex differences in the neural circuit that mediates female sexual receptivity. Frontiers in Neuroendocrinology 32 124-136. (doi:10.1016/j.yfrne.2011.02.008)

Gilchrist RB, Ritter LJ \&Armstrong DT 2004 Oocyte-somatic cell interactions during follicle development in mammals. Animal Reproduction Science 82-83 431-446. (doi:10.1016/j.anireprosci.2004.05.017)

Huang Y, Yao XL, Meng JZ, Liu Y, Jiang XL, Chen JW, Li PF, Ren YS, Liu WZ, Yao JB et al. 2016 Intrafollicular expression and potential regulatory role of cocaine- and amphetamine-regulated transcript in the ovine ovary. Domestic Animal Endocrinology 54 30-36. (doi:10.1016/j. domaniend.2015.09.001)

Juengel JL, Davis GH \& McNatty KP 2013 Using sheep lines with mutations in single genes to better understand ovarian function. Reproduction 146 R111-R123. (doi:10.1530/REP-12-0509)

Juengel JL \& McNatty KP 2005 The role of proteins of the transforming growth factor-beta superfamily in the intraovarian regulation of follicular development. Human Reproduction Update 11 143-160. (doi:10.1093/ humupd/dmh061)

Kobayashi Y, Jimenez-Krassel F, Li Q, Yao J, Huang R, Ireland J, Coussens PM \& Smith GW 2004 Evidence that cocaine- and amphetamine-regulated transcript is a novel intraovarian regulator of follicular atresia. Endocrinology 145 5373-5383. (doi:10.1210/en.20040283)

Kobayashi Y, Jimenez-Krassel F, Ireland JJ \& Smith GW 2006 Evidence of a local negative role for cocaine and amphetamine regulated transcript (CART), inhibins and low molecular weight insulin like growth factor binding proteins in regulation of granulosa cell estradiol production during follicular waves in cattle. Reproductive Biology and Endocrinology 4 22. (doi:10.1186/1477-7827-4-22)

Landau S, Bor A, Leibovich H, Zoref Z, Nitsan Z \& Madar Z 1995 The effect of ruminal starch degradability in the diet of Booroola crossbred ewes on induced ovulation rate and prolificacy. Animal Reproduction Science 38 97-108. (doi:10.1016/0378-4320(94)01355-P)

Lv L, Jimenez-Krassel F, Sen A, Bettegowda A, Mondal M, Folger JK, Lee KB, Ireland JJ \& Smith GW 2009 Evidence supporting a role for cocaine- and amphetamine-regulated transcript (CARTPT) in control of 
granulosa cell estradiol production associated with dominant follicle selection in cattle. Biology of Reproduction 81 580-586. (doi:10.1095/ biolreprod.109.077586)

Mandiki SNM, Noël B, Bister JL, Peeters R, Beerlandt G, Decuypere E, Visscher A, Sueß R, Kaulfuß KH \& Paquay R 2000 Pre-ovulatory follicular characteristics and ovulation rates in different breed crosses, carriers or non-carriers of the Booroola or Cambridge fecundity gene. Animal Reproduction Science 63 77-88. (doi:10.1016/S03784320(00)00147-0)

McLeod BJ, Fenton LF, Davis GH, Bruce GD, Manley TR \& Johnstone PD 1997 Identifying infertile homozygous Inverdale (FecXI) ewe lambs on the basis of genotype differences in reproductive hormone concentrations. Animal Reproduction Science 47 291-302. (doi:10.1016/S03784320(97)00020-1)

McNatty KP, Henderson KM, Lun S, Heath DA, Ball K, Hudson NL, Fannin J, Gibb M, Kieboom LE \& Smith P 1985 Ovarian activity in Booroola X Romney ewes which have a major gene influencing their ovulation rate. Journal of Reproduction and Fertility 73 109-120. (doi:10.1530/jrf.0.0730109)

McNatty KP, Hudson N, Henderson KM, Gibb M, Morrison L, Ball K \& Smith P 1987 Differences in gonadotrophin concentrations and pituitary responsiveness to $\mathrm{GnRH}$ between Booroola ewes which were homozygous (FF), heterozygous $(\mathrm{F}+)$ and non-carriers $(++)$ of a major gene influencing their ovulation rate. Journal of Reproduction and Fertility 80 577-588. (doi:10.1530/jrf.0.0800577)

McNatty KP, Fisher M, Collins F, Hudson NL, Heath DA, Ball K \& Henderson KM 1989 Differences in the plasma concentrations of $\mathrm{FSH}$ and $\mathrm{LH}$ in ovariectomized Booroola FF and ++ ewes. Journal of Reproduction and Fertility 85 705-713. (doi:10.1530/jrf.0.0850705)

McNatty KP, Hudson NL, Shaw L \& Moore L 1994 Plasma concentrations of $\mathrm{FSH}, \mathrm{LH}$, thyroid-stimulating hormone and growth hormone after exogenous stimulation with GnRH, TRH and GHRH in Booroola ewes that are homozygous carriers or non-carriers of the FecB gene. Journal of Reproduction and Fertility 102 177-183. (doi:10.1530/ jrf.0.1020177)

McNatty KP, Heath DA, Hudson NL, Lun S, Juengel JL \& Moore LG 2009 Gonadotrophin-responsiveness of granulosa cells from bone morphogenetic protein 15 heterozygous mutant sheep. Reproduction 138 545-551. (doi:10.1530/REP-09-0154)

Menchaca A, Vilarino M, Crispo M, de Castro T \& Rubianes E $2010 \mathrm{New}$ approaches to superovulation and embryo transfer in small ruminants. Reproduction, Fertility, and Development 22 113-118. (doi:10.1071/ RD09222)

Mihm M \& Evans AC 2008 Mechanisms for dominant follicle selection in monovulatory species: a comparison of morphological, endocrine and intraovarian events in cows, mares and women. Reproduction in Domestic Animals 43 (Supplement 2) 48-56. (doi:10.1111/j.14390531.2008.01142.x)

Montgomery GW, Bray AR \& Kelly RW 1983 Ovulation rates of first cross booroola compared with local breed ewes following differential feeding. Animal Reproduction Science 6 209-215. (doi:10.1016/03784320(83)90039-8)

Phillips DJ, Hudson NL \& McNatty KP 1993 Effects of ovariectomy and genotype on bioactive FSH in plasma and pituitary of Booroola ewes. Journal of Reproduction and Fertility 98 559-565. (doi:10.1530/ jrf.0.0980559)

Quirk SM, Cowan RG, Harman RM, Hu CL \& Porter DA 2004 Ovarian follicular growth and atresia: the relationship between cell proliferation and survival. Journal of Animal Science 82 (E-Supplement) E40-E52. (doi:10.2527/2004.8213_supplE40x)

Rogge G, Jones D, Hubert GW, Lin Y \& Kuhar MJ 2008 CART peptides: regulators of body weight, reward and other functions. Nature Reviews: Neuroscience 9 747-758. (doi:10.1038/nrn2493)

Scaramuzzi RJ, Campbell BK, Downing JA, Kendall NR, Khalid M, MunozGutierrez M \& Somchit A 2006 A review of the effects of supplementary nutrition in the ewe on the concentrations of reproductive and metabolic hormones and the mechanisms that regulate folliculogenesis and ovulation rate. Reproduction Nutrition Development 46 339-354. (doi:10.1051/rnd:2006016)

Scaramuzzi RJ, Baird DT, Campbell BK, Driancourt MA, Dupont J, Fortune JE, Gilchrist RB, Martin GB, McNatty KP, McNeilly AS et al. 2011 Regulation of folliculogenesis and the determination of ovulation rate in ruminants. Reproduction, Fertility, and Development 23 444-467. (doi:10.1071/RD09161)

Selvaraju S, Folger JK, Gupta PS, Ireland JJ \& Smith GW 2013 Stagespecific expression and effect of bone morphogenetic protein 2 on bovine granulosa cell estradiol production: regulation by cocaine and amphetamine regulated transcript. Domestic Animal Endocrinology 44 115-120. (doi:10.1016/j.domaniend.2012.10.002)

Sen A, Bettegowda A, Jimenez-Krassel F, Ireland JJ \& Smith GW 2007 Cocaine- and amphetamine-regulated transcript regulation of folliclestimulating hormone signal transduction in bovine granulosa cells. Endocrinology 148 4400-4410. (doi:10.1210/en.2007-0332)

Sen A, Lv L, Bello N, Ireland JJ \& Smith GW 2008 Cocaine- and amphetamine-regulated transcript accelerates termination of folliclestimulating hormone-induced extracellularly regulated kinase $1 / 2$ and Akt activation by regulating the expression and degradation of specific mitogen-activated protein kinase phosphatases in bovine granulosa cells. Molecular Endocrinology 22 2655-2676. (doi:10.1210/me.2008-0077)

Shackell GH, Hudson NL, Heath DA, Lun S, Shaw L, Condell L, Blay LR \& McNatty KP 1993 Plasma gonadotropin concentrations and ovarian characteristics in Inverdale ewes that are heterozygous for a major gene (FecX1) on the $\mathrm{X}$ chromosome that influences ovulation rate. Biology of Reproduction 48 1150-1156. (doi:10.1095/biolreprod48.5.1150)

Shorten PR, O'Connell AR, Demmers KJ, Edwards SJ, Cullen NG \& Juengel JL 2013 Effect of age, weight, and sire on embryo and fetal survival in sheep. Journal of Animal Science 91 4641-4653. (doi:10.2527/jas.2013-6415)

Silva JR, Figueiredo JR \& van den Hurk R 2009 Involvement of growth hormone $(\mathrm{GH})$ and insulin-like growth factor (IGF) system in ovarian folliculogenesis. Theriogenology 71 1193-1208. (doi:10.1016/j. theriogenology.2008.12.015)

Smith GW, Sen A, Folger JK \& Ireland JJ 2011 Putative role of cocaineand amphetamine-regulated transcript (CARTPT) in dominant follicle selection in cattle. In Reproduction in Domestic Ruminants VII, pp 105-117. Nottingham University Press: Nottingham, United Kingdom. (doi:10.5661/rdr-vii-105)

Souza CJ, Campbell BK, Webb R \& Baird DT 1997 Secretion of inhibin A and follicular dynamics throughout the estrous cycle in the sheep with and without the Booroola gene (FecB). Endocrinology 138 5333-5340. (doi:10.1210/en.138.12.5333)

Tisdall DJ, Watanabe K, Hudson NL, Smith P \& McNatty KP 1995 FSH receptor gene expression during ovarian follicle development in sheep. Journal of Molecular Endocrinology 15 273-281. (doi:10.1677/ jme.0.0150273)

van Wely M, Kwan I, Burt AL, Thomas J, Vail A, Van der Veen F \& AlInany HG 2011 Recombinant versus urinary gonadotrophin for ovarian stimulation in assisted reproductive technology cycles. Cochrane Database of Systematic Reviews 2 CD005354. (doi:10.1002/14651858. cd005354.pub2)

Webb R \& Campbell BK 2007 Development of the dominant follicle: mechanisms of selection and maintenance of oocyte quality. Society of Reproduction and Fertility Supplement 64 141-163. (doi.org/10.5661/ rdr-vi-141)

Wilson T, Wu XY, Juengel JL, Ross IK, Lumsden JM, Lord EA, Dodds KG, Walling GA, McEwan JC, O'Connell AR et al. 2001 Highly prolific Booroola sheep have a mutation in the intracellular kinase domain of bone morphogenetic protein IB receptor (ALK-6) that is expressed in both oocytes and granulosa cells. Biology of Reproduction 64 1225-1235. (doi:10.1095/biolreprod64.4.1225)

Yao J, Ren X, Ireland J, Coussens PM, Smith TP \& Smith GW 2004 Generation of a bovine oocyte cDNA library and microarray: resources for identification of genes important for follicular development and early embryogenesis. Physiological Genomics 19 84-92. (doi:10.1152/ physiolgenomics.00123.2004)

Received 22 September 2016

First decision 13 October 2016

Revised manuscript received 16 January 2017

Accepted 23 January 2017 